\title{
PENINGKATAN PEMAHAMAN SISWA PADA MATERI KOLOID MENGGUNAKAN PEMBELAJARAN MODEL SIKLUS BELAJAR 5E KELAS XI SMAN 2 PONTIANAK
}

\author{
Rody Putra Sartika, Ira Lestari \\ Dosen Pendidikan Kimia FKIP UNTAN \\ Email: rodyputrasartika@gmail.com
}

\begin{abstract}
The purposes of this study are 1) to determine difference of conceptual understanding of SMA 2 Pontianak students before and after being taught through 5 E learning cycle model on colloid subject matter, and 2) to describe conceptual understanding of SMAN 2 Pontianak Students before and after being taught through 5E learning cycle model on colloid material. This study was conducted in form of pre experimental design. Independent variables were learning before and after being taught through $5 E$ learning cycle model. Dependent variable was students conceptual understanding. To collect data, assessment technique was applied and achievement test was used to get data. Data were analyzed by means of inferential and descriptive statistic. Result of statistic showed P-value $=0,000<\alpha=0.05$ which means that there was a difference of students conceptual understanding before and after being taught through $5 E$ learning cycle model on colloid subject matter. Improvement of students conceptual understanding was 0,31 which means on average level.

Key words: conceptual understanding, $5 E$ learning cycle model.
\end{abstract}

Kimia sebagai bagian dari sains seharusnya dapat memberikan suatu strategi yang menarik dan menyenangkan di dalam proses pembelajarannya, hal ini disebabkan karena mata pelajaran kimia merupakan salah satu mata pelajaran yang sulit bagi siswa. Menurut Sirhan (2007) topik kimia umumnya terkait dengan struktur dari suatu materi, hal ini membuat kimia menjadi pelajaran yang sulit bagi siswa. Selain itu, kimia merupakan mata pelajaran yang banyak mempelajari konsep abstrak (Adaminata \& Marsih, 2011), memerlukan komitmen waktu dan usaha dari siswa (Wu \& Foos, 2010).
Keabstrakan pada materi kimia ditambah dengan adanya konsep yang berlawanan dengan intuisi, menjadikan kimia sebagai pelajaran yang kompleks, sehingga menyebabkan hasil belajar siswa menjadi rendah. Hasil nilai ulangan harian semester genap kelas XI IPA SMAN 2 Pontianak tahun ajaran 2013/2014 terlihat pada Tabel 1. Berdasarkan Tabel 1 konsep-konsep pada materi koloid masih belum dapat dipahami siswa dengan baik dan benar, sehingga memperoleh presentase ketidaktuntasan ulangan harian yang paling tinggi dengan kriteria ketuntasan minimum (KKM) sebesar 75 . 
Tabel 1. Persentase ulangan harian semester genap kelas XI IPA SMAN 2 Pontianak tahun ajaran 2013/2014.

\begin{tabular}{llcc}
\hline No & \multicolumn{1}{c}{ Materi } & $\begin{array}{c}\text { Ketuntasan siswa } \\
(\boldsymbol{\%})\end{array}$ & $\begin{array}{c}\text { Ketidaktuntasan } \\
\text { siswa (\%) }\end{array}$ \\
\hline 1 & Asam Basa & $48,6 \%$ & $51,4 \%$ \\
\hline 2 & Hidrolisis Garam & $21,6 \%$ & $78,4 \%$ \\
\hline 3 & Koloid & $18,1 \%$ & $81,9 \%$ \\
\hline 4 & $\begin{array}{l}\text { Kelarutan dan Hasil Kali } \\
\text { Kelarutan }\end{array}$ & $45,9 \%$ & $54,1 \%$ \\
\hline
\end{tabular}

Sumber : Daftar nilai guru mata pelajaran kimia

Hasil wawancara dengan siswa kelas XII IPA SMAN 2 Pontianak tanggal 22 Januari 2015, diperoleh informasi bahwa siswa mempelajari materi koloid masih dengan cara menghapal. Hasil wawancara dengan guru kimia SMAN 2 Pontianak tanggal 7 April 2015, diperoleh informasi bahwa guru menggunakan metode praktikum pada pembelajaran koloid, akan tetapi masih banyak siswa yang bertanya pada guru tentang prosedur kerja karena tidak tersedianya LKS. Pada saat siswa bertanya tentang materi koloid, guru langsung memberikan penjelasan kepada siswa tanpa memfasilitasi mereka untuk mengkonstruksi pengetahuannya secara mandiri. Pembelajaran yang demikian belum dapat memberikan pemahaman konsep yang utuh kepada siswa, karena guru masih berperan merupakan pusat informasi dan siswa sebagai penerima informasi. Pembelajaran kimia seharusnya dapat memberikan pemahaman konsep yang utuh kepada siswa. Menurut Silaholo (2008) suatu konsep kompleks hanya dapat dikuasai dengan baik dan benar bila konsep-konsep yang mendasari telah dikuasai dengan baik dan benar.

Pembelajaran yang masih berpusat pada guru belum dapat membantu siswa memahami konsep secara utuh, oleh sebab itu diperlukan pembelajaran yang berpusat pada siswa melalui pendekatan kontruktivis. Menurut Prawiradilaga (2009) konstruktivisme menyiapkan siswa untuk membentuk pemahaman dan pola pikir tersendiri. Paradigma baru dalam pembelajaran sains termasuk kimia adalah pembelajaran di mana siswa tidak hanya dituntut untuk lebih banyak mempelajari konsep-konsep dan prinsip-prinsip sains secara verbalistis, hafalan, pengenalan rumus-rumus, dan pengenalan istilah-istilah melalui serangkaian latihan secara verbal, namun hendaknya dalam pembelajaran sains (dalam hal ini kimia), guru lebih banyak memberikan pengalaman kepada siswa untuk lebih mengerti dan membimbing siswa agar dapat menggunakan pengetahuan kimianya tersebut dalam kehidupannya seharihari (Gallagher, 2007 dalam Sunyono, 2008).

Salah satu model pembelajaran dengan pendekatan konstruktivis yang dapat digunakan pada pembelajaran kimia untuk memberikan pemahaman konsep yang utuh dan melatih keterampilan berpikir kritis siswa adalah model siklus belajar (learning 
cycle/LC). Model siklus belajar merupakan salah satu strategi belajar yang menggunakan pendekatan konstruktivis. Secara filosofi belajar menurut teori konstruktivisme adalah individu harus mengkonstruksi pengetahuan dan memberi makna melalui pengalaman yang nyata serta proses belajar harus aktif dalam menerima pembelajaran. Model siklus belajar terdiri atas lima fase pembelajaran yang meliputi: Engagement, Exploration, Explanation, Elaboration, dan Evaluation (Lorsbach, 2002).

Fase engagement dilakukan dengan membuat koneksi ke pengalaman masa lalu dan mengekspos miskonsepsi siswa dan mereka harus mengurangi ketidakseimbangan kognitif yang terjadi. Guru mengakses pengetahuan siswa dan membantu mereka menjadi terlibat dalam sebuah konsep baru melalui penggunaan aktivitas singkat yang mendorong rasa ingin tahu dan menimbulkan pengetahuan sebelumnya. Kegiatan ini membuat hubungan antara pengalaman belajar masa lalu dan sekarang, terlebih dahulu mengungkapkan konsepsi, dan mengatur pemikiran siswa terhadap aktivitas hasil belajar saat ini.Guru melibatkan siswa dalam tugas belajar, di mana mental siswa berfokus pada obyek, masalah, situasi, atau peristiwa.

Mengajukan pertanyaan, mendefinisikan masalah, menunjukkan peristiwa yang tidak sesuai, dan bertindak keluar dari situasi masalah adalah cara-cara untuk melibatkan siswa dan fokus pada tugas pembelajaran. Peran guru adalah menyajikan situasi dan mengidentifikasi tugas pembelajaran.
Guru juga menetapkan aturan dan prosedur untuk menetapkan tugas. Engagement berhasil pada siswa yang bingung, dan secara aktif termotivasi dalam kegiatan belajar.

Setelah siswa melakukan kegiatan engagement, selanjutnya siswa memiliki kebutuhan psikologis untuk mengeksplorasi ide-ide. Kegiatan eksplorasi dirancang sedemikian rupa sehingga siswa di kelas memiliki kesamaan pengalaman konkret di mana mereka terus merumuskan konsep, proses, dan keterampilan. Fase engagement membawa ketidakseimbangan, eksplorasi memulai proses keseimbangan. Perangkat lunak pendidikan dapat digunakan dalam fase ini, namun harus dirancang hatihati untuk membantu proses awal merumuskan konsep yang memadai dan akurat secara ilmiah. Fase exploration dilakukan dengan membangun pengalaman guru dan siswa yang dapat digunakan kemudian untuk memperkenalkan dan mendiskusikan konsep, proses, atau keterampilan.

Selama kegiatan, siswa memiliki waktu di mana mereka dapat mengeksplorasi benda, peristiwa, atau situasi. Sebagai hasil dari keterlibatan mental dan fisik mereka dalam kegiatan tersebut, siswa membangun hubungan, mengamati pola, mengidentifikasi variabel, dan mengajukan pertanyaan. Peran guru dalam tahap eksplorasi adalah fasilitator atau pelatih. Guru memulai kegiatan dan memberikan waktu serta kesempatan kepada siswa untuk menyelidiki benda, bahan, dan situasi berdasarkan pada ide-ide masingmasing siswa dari fenomena. 
Guru dapat melatih atau membimbing siswa ketika mereka mulai merekonstruksi penjelasan mereka, dalam hal ini penggunaan bahan-bahan yang nyata dan pengalaman konkret sangat penting. Pengalaman eksplorasi memberikan siswa sebuah dasar aktivitas umum di mana konsep saat ini (yaitu, miskonsepsi), proses, dan keterampilan yang diidentifikasi dan perubahan konseptual yang difasilitasi. Siswa dapat menyelesaikan kegiatan laboratorium yang membantu mereka menggunakan pengetahuan sebelumnya untuk menghasilkan ideide baru, mengeksplorasi pertanyaan dan kemungkinan, serta desain dan melakukan penyelidikan awal.

Fase explanation dilakukan dengan meminta siswa menjelaskan pengalaman eksplorasi dan pengalaman engagement mereka dengan menggunakan istilah umum. Pertama, guru meminta siswa untuk memberikan penjelasan mereka. Kedua, guru memperkenalkan penjelasan ilmiah atau teknologi secara langsung, eksplisit, dan formal. Guru harus mendasarkan bagian awal dari fase ini pada penjelasan siswa dan secara jelas menghubungkan penjelasan dengan pengalaman dalam fase engagement dan eksplorasi. Kunci fase ini adalah untuk menyajikan konsep, proses, atau keterampilan singkat, sederhana, jelas, dan langsung dan untuk melanjutkan ke tahap berikutnya.

Tahap Penjelasan memfokuskan perhatian siswa pada aspek tertentu dari engagement dan pengalaman eksplorasi serta memberikan kesempatan untuk menunjukkan pemahaman konseptual mereka, keterampilan proses, atau perilaku. Fase ini juga memberikan kesempatan bagi guru untuk langsung memperkenalkan konsep, proses, atau keterampilan. Siswa menjelaskan pemahaman mereka tentang konsep. Penjelasan dari guru dapat membimbing mereka ke arah pemahaman yang lebih dalam, yang merupakan bagian penting dari fase ini.

Berbagai teknik dan strategi yang dimiliki guru dapat digunakan untuk memperoleh dan mengembangkan penjelasan siswa. Guru dapat menggunakan penjelasan verbal, tetapi dapat juga menggunakan strategi lain, seperti video, film, dan kursus pendidikan. Pada akhirnya, siswa harus mampu menjelaskan pengalaman eksplorasi dan pengalaman engagement mereka dengan menggunakan istilah umum. Siswa tidak akan dapat seketika mengekspresikan dan menerapkan pembelajaran, karena kegiatan penjelasan membutuhkan waktu.

Fase elaboration dilakukan dengan melibatkan siswa dalam situasi baru dan masalah yang memerlukan transfer penjelasan yang indentik atau mirip. Setelah siswa memiliki penjelasan dan syarat untuk tugas-tugas belajar mereka, penting untuk melibatkan siswa dalam pengalaman lanjutan yang lebih luas atau terperinci dari konsep, proses, atau keterampilan. Fase ini memfasilitasi transfer konsep untuk situasi sama yang terkait tetapi baru. Pada beberapa kasus, siswa masih mungkin memiliki miskonsepsi, atau mereka hanya dapat memahami konsep dalam hal pengalaman eksplorasi. Kegiatan elaborasi menyediakan waktu lebih lanjut dan 
pengalaman yang mendukung proses belajar.

Guru memberikan tantangan dan memperluas pemahaman konseptual dan keterampilan siswa. Melalui pengalaman baru, siswa mengembangkan pemahaman yang lebih dalam dan lebih luas, informasi lebih lanjut, dan keterampilan yang memadai. Siswa menerapkan pemahaman mereka tentang konsep dengan melakukan kegiatan tambahan. Diskusi kelompok dan situasi pembelajaran kooperatif memberikan kesempatan bagi siswa untuk mengekspresikan pemahaman mereka tentang subjek dan menerima umpan balik dari orang lain yang sangat dekat dengan tingkat pemahaman mereka. Fase ini juga merupakan kesempatan untuk melibatkan siswa dalam situasi dan masalah baru yang memerlukan transfer penjelasan yang identik atau mirip. Generalisasi konsep, proses, dan keterampilan adalah tujuan utama.

Fase evaluation dilakukan dengan memberikan penilaian terhadap pengetahuan, pemahaman konsep, atau kompetensi siswa dalam konteks baru yang kadang-kadang mendorong siswa belajar melakukan investigasi lebih lanjut, dengan cara refleksi pelaksanaan pembelajaran. Fase ini adalah kesempatan penting bagi siswa untuk menggunakan keterampilan yang telah mereka peroleh dan mengevaluasi pemahaman mereka. Selain itu, siswa harus menerima umpan balik pada kelayakan penjelasan mereka. Evaluasi informal dapat terjadi pada awal dan seluruh urutan fase-fase di dalam siklus belajar. Guru dapat menyelesaikan evaluasi formal setelah fase elaborasi. Fase ini merupakan tahap di mana guru mengelola penilaian untuk menentukan tingkat pemahaman setiap siswa. Tahap evaluasi mendorong siswa untuk menilai pemahaman dan kemampuan mereka dan memberikan kesempatan bagi guru untuk mengevaluasi kemajuan siswa untuk mencapai tujuan pendidikan.

Pada model siklus belajar, siswa dapat mengidentifikasi suatu pola keteraturan pada fenomena yang diselidiki, memperkenalkan konsepkonsep yang ada hubungannya dengan fenomena yang diselidiki dan mendiskusikannya dalam konteks apa yang telah diamati, kemudian menggunakan konsep-konsep tersebut pada situasi baru. Menurut Duran, Duran, Haney, \& Scheuermann (2011) siklus belajar merupakan model pembelajaran berbasis penelitian yang dapat membantu siswa mengeksplorasi konsep dalam sains dan membantu guru merencanakan pembelajaran yang bermakna dan pemahaman konsep yang mendalam. Penelitian yang dilakukan oleh Balci, Cakiroglu, \& Tekkaya, (2006) menunjukkan bahwa penggunaan siklus belajar dapat memperjelas proses berpikir dan memperbaiki miskonsepsi siswa. Berdasarkan penjelasan di atas, perlu dilakukan penelitian tentang implemetasi model siklus belajar 5E terhadap pemahaman konsep dan keterampilan berpikir kritis siswa SMAN 2 Pontianak pada materi koloid.

\section{METODE}

Bentuk penelitian ini adalah praexperiment design. Rancangan 
yang digunakan dalam penelitian ini adalah One Group Pretest-Postest Design dengan pola sebagai berikut:

$\begin{array}{lll}\mathrm{U}_{1} & \mathrm{~L} & \mathrm{U}_{2}\end{array}$

(Prabowo, 2011)

Keterangan:

$\mathrm{U}_{1}=$ Pretest .

$\mathrm{L}=$ Perlakuan penerapan model siklus belajar $5 \mathrm{E}$.

$\mathrm{U}_{2}=$ Posttest .

Populasi pada penelitian ini adalah siswa SMAN 2 Pontianak kelas XI IPA yang berjumlah 4 kelas. Teknik pemilihan sampel dilakukan dengan cara purposive sampling. Sampel pada penelitian ini adalah kelas MIA 1, dengan pertimbangan kelas tersebut memiliki ketuntasan hasil belajar yang rendah pada materi sebelumnya.

Variabel bebas pada penelitian ini adalah pembelajaran sebelum dan setelah menggunakan model siklus belajar 5E. Variabel terikat pada penelitian ini adalah pemahaman konsep siswa. Teknik pengumpulan data yang digunakan pada penelitian ini adalah pengukuran. Instrumen yang digunakan pada penelitian ini adalah tes hasil belajar yang berbentuk essay dengan rentang kriteria soal mulai dari C3 (menerapkan) sampai dengan C5 (mengevaluasi), sehingga semua item soal tersebut dapat digunakan untuk mengetahui pemahaman konsep siswa.

Teknik analisis data dilakukan analisis statistik inferensial dengan menggunakan SPSS 17 sebagai berikut:

1. Uji Normalitas

Uji normalitas dilakukan pada

data pretes dan postest. Bentuk hipotesis untuk uji normalitas adalah sebagai berikut:

$\mathrm{H}_{0}$ : data berasal dari populasi yang terdistribusi normal.

$\mathrm{H}_{1}$ : data berasal dari populasi yang terdistribusi tidak normal.

Pada pengujian hipotesis, kriteria untuk menolak atau tidak menolak $\mathrm{H}_{0}$ berdasarkan P-value (dalam program SPSS digunakan istilah Signifinance atau "Sig") adalah sebagai berikut (Stanislaus S U : 2009):

Jika $\mathrm{P}$-value $<\alpha$, maka $\mathrm{H}_{0}$ ditolak.

Jika $\mathrm{P}$-value $\geq \alpha$, maka $\mathrm{H}_{0}$ tidak dapat ditolak.

2. Uji perbedaan pretest dan posttest Peningkatan pemahaman konsep siswa secara signifikan ditentukan mengunakan uji Wilcoxon matched pairs pada data pretest dan posttest dengan hipotesis sebagai berikut:

$\mathrm{H}_{0}$ : Tidak terdapat peningkatan pemahaman konsep siswa pada materi koloid.

$\mathrm{H}_{1}$ : Terdapat peningkatan pemahaman konsep siswa pada materi koloid.

Kriteria untuk menolak atau tidak menolak $\mathrm{H}_{0}$ berdasarkan $\mathrm{P}$-value adalah sebagai berikut (Stanislaus, 2009):

Jika $\mathrm{P}$-value $<\alpha$, maka $\mathrm{H}_{0}$ ditolak

Jika $\mathrm{P}$ - value $\geq \alpha$, maka $\mathrm{H}_{0}$ tidak dapat ditolak.

Kriteria peningkatan pemahaman konsep siswa pada materi koloid ditentukan menggunakan rumus skor gain ternormalisasi (Hake, 1999) sebagai berikut:

$\langle\mathrm{g}>=\%<\mathrm{G}>/ \%<\mathrm{G}>\max$

$$
=\left(\%<\mathrm{S}_{\mathrm{f}}>-\%<\mathrm{S}_{\mathrm{i}}>\right) /(100-\%<\mathrm{Si}>)
$$

Keterangan:

$\langle\mathrm{g}\rangle=$ Rata-rata gain ternormalisasi.

$\langle\mathrm{G}\rangle=$ Rata-rata gain . 
$\left\langle\mathrm{S}_{\mathrm{f}}\right\rangle=$ Rata-rata posttest kelas.

$\left\langle\mathrm{S}_{\mathrm{i}}\right\rangle=$ Rata-rata pretest kelas.

Kriteria perolehan skor gain ternormalisasi diklasifikasikan ke dalam tiga tingkatan pada Tabel 2 .

Tabel 2. Klasifikasi normalisasi gain (Hake, 1999).

\begin{tabular}{cc}
\hline $\begin{array}{c}\text { Koefisien } \\
\text { Normalisasi gain }\end{array}$ & Klasifikasi \\
\hline $\mathrm{g}<0,3$ & Rendah \\
\hline $0,3 \leq \mathrm{g}<0,7$ & Sedang \\
\hline $\mathrm{g} \geq 0,7$ & Tinggi \\
\hline
\end{tabular}

\section{HASIL DAN PEMBAHASAN}

Rata-rata hasil belajar siswa pada saat pretest dan posttest dapat dilihat pada Tabel 3.

Tabel 3. Hasil belajar siswa.

\begin{tabular}{ccc}
\hline & Pretest & Posttest \\
\hline Rata-rata & 13.23 & 18.07 \\
\hline Varians & 16.29 & 9.77 \\
\hline $\begin{array}{c}\text { Standart } \\
\text { Deviasi }\end{array}$ & 4.04 & 3.13 \\
\hline
\end{tabular}

Berdasarkan nilai KKM di sekolah sebesar 75, sebanyak 2 siswa $(5.41 \%)$ tuntas pada pretest dan 11 siswa (29.73) tuntas pada posttest.

1. Uji normalitas

Hasil uji normalitas pretest pada kelas eksperimen dan kelas kontrol dapat dilihat pada Tabel 4. Hasil uji normalitas pretest dan posttest terlihat bahwa $\mathrm{P}$-value pretest $=0,167>\alpha=0,05$, sedangkan Pvalue posttest $=0,314>\alpha=0,05$. Hasil uji normalitas ini dapat disimpulkan data pretest dan posttest berasal dari populasi yang terdistribusi normal.

Tabel 4. Hasil uji normalitas pretest dan posttest.

\begin{tabular}{lccc}
\hline & \multicolumn{3}{c}{ Shapiro-Wilk } \\
\cline { 2 - 4 } & Statistic & Df & Sig. \\
\hline Pretest & .957 & 37 & .167 \\
\hline Posttest & .966 & 37 & .314 \\
\hline
\end{tabular}

Perbedaan pemahaman konsep siswa sebelum dan setelah pembelajaran menggunakan model siklus belajar 5E pada materi koloid dapat diketahui dengan melakukan uji $\mathrm{t}$ dua sampel berpasangan, karena data pretest dan posttest terdistribusi normal.

Tabel 5 Hasil uji t dua sampel berpasangan pemahaman konsep siswa.

\begin{tabular}{|c|c|c|c|c|c|c|c|c|c|}
\hline \multicolumn{10}{|c|}{ Paired Samples Test } \\
\hline & & \multicolumn{5}{|c|}{ Paired Differences } & \multirow[b]{3}{*}{$\mathrm{t}$} & \multirow[b]{3}{*}{ df } & \multirow{3}{*}{$\begin{array}{l}\text { Sig. (2- } \\
\text { tailed) }\end{array}$} \\
\hline & & \multirow[b]{2}{*}{ Mean } & \multirow{2}{*}{$\begin{array}{c}\text { Std. } \\
\text { Deviation }\end{array}$} & \multirow{2}{*}{$\begin{array}{l}\text { Std. } \\
\text { Error } \\
\text { Mean }\end{array}$} & \multicolumn{2}{|c|}{$\begin{array}{l}95 \% \text { Confidence Interval } \\
\text { of the Difference }\end{array}$} & & & \\
\hline & & & & & Lower & Upper & & & \\
\hline Pair 1 & $\begin{array}{l}\text { Posttest } \\
\text { Kelas } \\
\text { Eksperimen } \\
\text { - Pretest } \\
\text { Kelas } \\
\text { Eksperimen }\end{array}$ & 4.81081 & 4.51748 & .74267 & 3.30461 & 6.31701 & 6.478 & 36 & .000 \\
\hline
\end{tabular}


Hasil uji t dua sampel berpasangan dengan P-value $=0,000<\alpha=0,05$, artinya Ho dapat ditolak. Hasil uji t dua sampel berpasangan dapat disimpulkan terdapat perbedaan pemahaman konsep siswa sebelum dan setelah pembelajaran mengunakan model siklus belajar pada materi koloid.

2. Peningkatan pemahaman konsep siswa.
Pemahaman konsep siswa kelas eksperimen yang diajarkan menggunakan pembelajaran model siklus belajar 5E pada materi koloid diperoleh dari hasil belajar siswa dari pretest dan posttest. Peningkatan pemahaman konsep siswa pada kelas eksperimen ditentukan menggunakan rumus $\mathrm{N}$-Gain yang dapat dilihat pada Tabel 6.

Tabel 6. Peningkatan pemahaman konsep siswa.

\begin{tabular}{ccrccccc}
\hline No. & $\begin{array}{c}\text { Kode } \\
\text { siswa }\end{array}$ & N-Gain & $\begin{array}{c}\text { Peningkatan } \\
\text { pemahaman } \\
\text { konsep }\end{array}$ & No. & $\begin{array}{c}\text { Kode } \\
\text { siswa }\end{array}$ & N-Gain & $\begin{array}{c}\text { Peningkatan } \\
\text { pemahaman } \\
\text { konsep }\end{array}$ \\
\hline 1 & E1 & 0.46 & Sedang & 20 & E20 & 0.33 & Sedang \\
\hline 2 & E2 & 0.68 & Sedang & 21 & E21 & 0.69 & Sedang \\
\hline 3 & E3 & -0.58 & Rendah & 22 & E22 & 0.59 & Sedang \\
\hline 4 & E4 & 0.46 & Sedang & 23 & E23 & 0.38 & Sedang \\
\hline 5 & E5 & 0.27 & Rendah & 24 & E24 & 0.59 & Sedang \\
\hline 6 & E6 & -0.65 & Rendah & 25 & E25 & 0.41 & Sedang \\
\hline 7 & E7 & 0.55 & Sedang & 26 & E26 & -0.10 & Rendah \\
\hline 8 & E8 & 0.21 & Rendah & 27 & E27 & 0.25 & Rendah \\
\hline 9 & E9 & -0.07 & Rendah & 28 & E28 & 0.45 & Sedang \\
\hline 10 & E10 & -0.24 & Rendah & 29 & E29 & 0.67 & Sedang \\
\hline 11 & E11 & -0.29 & Rendah & 30 & E30 & 0.31 & Sedang \\
\hline 12 & E12 & 0.73 & Tinggi & 31 & E31 & 0.65 & Sedang \\
\hline 13 & E13 & 0.31 & Sedang & 32 & E32 & 0.22 & Rendah \\
\hline 14 & E14 & 0.15 & Rendah & 33 & E33 & 0.25 & Rendah \\
\hline 15 & E15 & 0.61 & Sedang & 34 & E34 & 0.33 & Sedang \\
\hline 16 & E16 & 0.68 & Sedang & 35 & E35 & 0.46 & Sedang \\
\hline 17 & E17 & 0.50 & Sedang & 36 & E36 & 0.19 & Rendah \\
\hline 18 & E18 & 0.51 & Sedang & 37 & E37 & 0.14 & Rendah \\
\hline 19 & E19 & 0.41 & Sedang & & & & \\
\hline & & & & & & & \\
\hline
\end{tabular}

Berdasarkan Tabel 6 diperoleh peningkatan pemahaman konsep siswa secara klasikal sebesar $37.84 \%$ berada pada kategori rendah, $49.46 \%$ berada pada kategori sedang, dan $2.70 \%$ berada pada kategori tinggi. Rata-rata peningkatan pemahaman konsep siswa secara klasikal sebesar 0.31 berada pada kategori sedang, hal ini menunjukkan bahwa prakonsepsi siswa mengalami perubahan setelah diberikan pembelajaran dengan mengunakan model siklus belajar 5E pada materi koloid. Menurut Ibrahim (2012) prakonsepsi akan berubah manakala siswa yang bersangkutan diajarkan konsep yang sebenarnya.

Terjadinya peningkatan pemahaman konsep siswa secara signifikan setelah diberikan 
perlakuan menggunakan model siklus belajar 5E pada materi koloid karena model ini dapat membuat siswa menjadi aktif dan memberikan pengalaman langsung dalam mempelajari kompetensi-kompetensi yang ingin dicapai. Model ini terdiri atas lima fase pembelajaran yang meliputi: fase engagement, fase exploration, fase explanation, fase elaboration dan fase evaluation. Fase engagement membuat hubungan antara pengalaman belajar siswa pada masa lalu dan saat ini, dengan terlebih dahulu mengungkap konsepsi siswa melalui pertanyaanpertanyaan dari fenomena yang ditemukan di dalam kehidupan sehari-hari sesuai dengan konsep yang akan dipelajari. Pada fase ini terjadi proses asimilasi dimana siswa menggunakan struktur kognitif yang sudah ada untuk merespon informasi baru yang diterimanya, sehingga dapat mengurangi ketidakseimbangan kognitif yang terjadi dan secara aktif termotivasi dalam pembelajaran.

Setelah melakukan fase engagement, selanjutnya siswa mengeksplorasi ide-ide melalui fase exploration. Fase ini membangun pengalaman siswa untuk memperkenalkan dan mendiskusikan konsep dengan bantuan lembar kerja siswa (LKS). Siswa difasilitasi dengan LKS untuk menyelesaikan kegiatan praktikum yang membantu mereka menggunakan pengetahuan sebelumnya untuk menghasilkan ideide baru dan mengeksplorasi pertanyaan-pertanyaan yang muncul sehingga memulai proses keseimbangan. Dalam hal ini, tidak semua konsep baru dapat diasimilasi ke dalam skema yang telah dimiliki siswa yang pada akhirnya terjadi proses akomodasi. Proses keseimbangan diperlukan untuk mengatur keseimbangan antara proses asimilasi dan akomodasi. Dengan demikian, siswa dapat menyatukan konsep baru yang diterimanya dengan struktur kognitif yang telah ada (skema). Menurut Piaget pengetahuan tidak statis, tetapi terus berkembang dan berubah secara konstan selama siswa mengkonstruksi pengalamanpengalaman baru yang memaksa mereka untuk membangun dan memodifikasi pengetahuan sebelumnya (Arends, 2008).

Pada fase exploration siswa dibentuk ke dalam kelompok heterogen yang dapat membantu siswa secara aktif membangun konsep-konsepnya sendiri dengan cara berinteraksi dengan lingkungan sosialnya, baik dengan bimbingan dari guru maupun kerjasama dengan teman sebayanya dalam satu kelompok dalam melaksanakan praktikum sesuai dengan LKS yang diberikan. Pemikiran Vygotsky percaya bahwa interaksi sosial dengan orang lain memacu pengkonstruksian ide-ide baru dan meningkatkan perkembangan intelektual siswa dan Bruner juga menekankan pentingnya membantu siswa untuk memahami struktur atau ide-ide kunci suatu disiplin ilmu, kebutuhan akan keterlibatan aktif siswa dalam proses belajar, dan keyakinan bahwa pembelajaran sejati terjadi melalui personal discovery (penemuan pribadi) (Arends, 2008).

Fase explanation mendorong siswa untuk menjelaskan pemahaman konsep yang telah diperoleh pada fase engagement dan fase explaration 
dengan kalimat mereka, meminta bukti dan klarifikasi dari penjelasan mereka dan mengarahkan pada kegiatan diskusi. Melalui fase ini siswa dapat menemukan istilah-istilah dari konsep yang telah dipelajari. Guru memberikan penjelasan singkat kepada siswa terhadap fenomenafenomena yang mereka amati pada fase exploration untuk membimbing siswa ke arah pemahaman konsep yang lebih mendalam. Menurut Byber, Taylor, Gardner, Pamela Van Scotter, \& Landes (2006) penjelasan dari guru atau kurikulum dapat membimbing mereka menuju pemahaman yang lebih dalam, yang merupakan bagian penting dari fase ini. Penjelasan tersebut diharapkan dapat mereduksi kesalahan-kesalahan konsep yang terjadi dan siswa dapat memperoleh pemahaman konsep yang utuh.

Fase elaboration memfasilitas transfer konsep untuk situasi yang sama tetapi baru dengan bantuan LKS lanjutan. Siswa melakukan praktikum lanjutan sesuai dengan LKS lanjutan yang diberikan untuk mengembangkan pemahaman konsep yang lebih dalam dan luas. Diskusi kelompok dan situasi pembelajaran yang kooperatif dapat memberikan kesempatan pada siswa untuk mengekspresikan pemahaman mereka tentang materi yang dipelajari. Fase ini memberikan kesempatan kepada siswa untuk terlibat dalam situasi dan masalah baru yang memerlukan transfer penjelasan yang indentik, sehingga pembelajaran menjadi lebih bermakna karena siswa diharapkan mampu mengaitkan situasi dan masalah baru dengan struktur kognitif yang telah ada. Menurut pemikiran Ausabel makna dapat muncul dari materi baru hanya bila materi itu terkait dengan struktur kognitif dari pembelajaran sebelumnya (Arends, 2008).

Fase terakhir pada model siklus belajar adalah evaluation yang merupakan kesempatan bagi guru untuk menilai pemahaman konsep siswa. Siswa diminta untuk mengerjakan latihan soal untuk mengetahui pemahaman konsep untuk materi koloid. Pada penelitian ini terdapat lima siswa yang mengalami penurunan pemahaman konsep. Siswa dengan kode E9 mengalami penurunan pada indikator 1 tentang membedakan suspensi, koloid dan larutan. Pada posttest siswa tersebut tidak dapat memberikan perbedaan antara suspense, koloid dan suspense, padahal jawaban yang diberikan pada saat pretest benar. Siswa dengan kode E3, E6 dan E26 juga mengalami penurunan pada indikator 1 dan indikator 3 tentang membedakan cara pembuatan koloid. Pada posttest ketiga siswa tersebut tidak dapat mengklasifikasikan pembuatan koloid secara kondesasi dan dispersi dan memberikan perbedaan pembuatan koloid secara kondensasi dan dispersi padahal jawaban yang diberikan pada saat pretest juga benar.

Selain itu, siswa dengan kode E10 mengalami penurunan pada indikator1, indikator 3, dan indikator 5 tentang peranan koloid di dalam kehidupan sehari-hari. Pada posttest siswa tersebut tidak dapat menjelaskan peranan koloid dalam kehidupan sehari-hari padahal jawaban yang diberikan pada saat pretest benar. Siswa yang mengalami penurunan pemahaman konsep disebabkan karena pemahaman konsep mereka terhadap materi koloid 
setelah diajarkan menggunakan model siklus belajar 5E masih belum utuh, yang dapat disebabkan oleh beberapa faktor. Menurut Prasetya dalam Amaliyanti (2013) faktor-faktor tersebut antara lain: a) Faktor raw input (faktor murid/anak itu sendiri) dimana tiap anak memiliki kondisi yang berbeda-beda dalam: (1) Kondisi fisiologis, (2) Kondisi psikologis; b) Faktor enviromental input (faktor lingkungan), baik lingkungan alami ataupun lingkungan sosial; c) Faktor instrumental input, antara lain terdiri dari: (1) Kurikulum, (2) Program/bahan pengajaran, (3) Sarana dan fasilitas dan, (4) Guru (tenaga pengajar).

\section{SIMPULAN DAN SARAN} adalah:

Simpulan pada penelitian ini

1. Terdapat perbedaan pemahaman konsep siswa kelas XI SMAN 2 Pontianak setelah diajarkan menggunakan model siklus belajar $5 \mathrm{E}$ pada materi koloid.

2. Rata-rata peningkatan pemahaman konsep siswa kelas XI SMAN 2 Pontianak setelah diajarkan menggunakan model siklus belajar 5E pada materi koloid sebesar 0.31 dengan kaegori sedang.

Saran pada penelitian ini sebaiknya emberikan lebih banyak perhatian dan bimbingan kepada siswa pada fase exploration dan fase elaboration, sehingga waktu diperlukan kedua fase tersebut dapat dimanfaatkan secara efektif.

\section{DAFTAR PUSTAKA}

Adaminata, M. A., \& Marsih, I. N. (2011). Analisis Kesalahan Konsep Siswa SMA pada Pokok Bahasan
Kesetimbangan
Kimia.
Retrieved Januari 27, 2013, from google.com: http://portal.fi.itb.ac.id/cps/

Amaliyanti. (2013). Pemahaman Siswa Dalam Proses Belajar. Retrieved September 15, 2013, from Cirukem Media Informasi:

http://cirukem.org/pendidikancirukem/penelitian.

Arends, R. I. (2008). Learning To Teach Edisi Ketujuh. Yokyakarta: Pustaka Pelajar.

Balci, S., Cakiroglu, J., \& Tekkaya, C. (2006). Enggagement, Exploration, Explanation, Extension, and Evaluation (5E) Learning Cycle and Conceptual Change Text as Learning Tools. Biochemistry and Molecular Biology Education, Vol. 34, No. 3, 199-203.

Byber, R. W., Taylor, J. A., Gardner, A., Pamela Van Scotter, J. C., \& Landes, N. (2006). The BSCS 5E Instructional Model: Origins and Effectiveness. Colorado Springs: BSCS.

Duran, E., Duran, L., Haney, J., \& Scheuermann, A. (2011). A Learning Cycle for All Student. Ohio: Sci Links.

Hake, R. R. (1999). Analyzing Change/Gain Scores . USA: Dept. of Physics, Indiana University.

Ibrahim, M. (2005). Asesmen Berkelanjutan Konsep Dasar, Tahapan Pengembangan dan 
43 Jurnal Pendidikan Matematika dan IPA Vol. 7 No. 2 Juli 2016: 32-43

Contoh. Surabaya: Unesa University Press.

Lorsbach, A. (2002). The Learning Cycle as A Tool for Planning Science Instruction. Retrieved Desember 10, 2002, from http://www.coe.ilstu.edu/scien ceed/lorsbach/257lrcy.html.

Prabowo. (2011). Metodelogi Penelitian (Sains dan Pendidikan Sains). Surabaya: Unesa University Press.

Prawiradilaga, D. S. (2009). Prinsip Disain Pembelajaran. Jakarta : Kencana.

Sihaloho, M. (2008). Analisis Pemahaman Konsep Pergeseran Kesetimbangan Kimia pada Tingkat
Makroskopis dan Mikroskopis siswa di SMA Negeri Gorontalo. Retrieved Oktober 14, 2012, from journal.ung.ac.id/ filejurnal/.../MSVol5No2_06. pdf: www.google.com

Sirhan, G. (2007). Learning Difficulties in Chemistry: An Overview . Journal of TURKISH SCIENCE EDUCATION, 2-20.

Stanislaus, U. (2009). Pedoman Analisi Data dengan SPSS. Yokyakarta: Graha Ilmu.

Wu, C., \& Foos, J. (2010). Making Chemistry Fun to Learn . Literacy Information and Computer Education Journal (LICEJ), 3-7. 